\title{
Allelopathy of Pinus taeda needles on the Germination and Initial Growth of Brachiaria riziziensis
}

\author{
${ }^{1}$ David Marlon Dalposso, ${ }^{2}$ Edson Bertoldo, ${ }^{3}$ Thayllane de Campos Siega, ${ }^{4}$ Pedro Valério Dutra Moraes, ${ }^{5}$ Maira Cristina \\ Schuster, ${ }^{6}$ Lucas Link, ${ }^{7}$ Alexandre Defaveri
}

${ }^{1}$ Postgraduate Program in Agroecosystems (PPGSIS), Federal Technological University of Paraná (UTFPR), Dois Vizinhos, Paraná, Brazil.

${ }^{2}$ Postgraduate Program in Agronomy (PPGAG), Federal Technological University of Paraná (UTFPR), Pato Branco, Paraná, Brazil.

${ }^{3}$ Postgraduate Program in Agronomy (PPGAG), Federal Technological University of Paraná (UTFPR), Pato Branco, Paraná, Brazil.

${ }^{4}$ Department of Agronomy, Federal Technological University of Paraná (UTFPR), Dois Vizinhos, Paraná, Brazil.

${ }^{5}$ Postgraduate Program in Agronomy (PPGAG), Federal Technological University of Paraná (UTFPR), Pato Branco, Paraná, Brazil.

${ }^{6}$ Postgraduate Program in Agroecosystems (PPGSIS), Federal Technological University of Paraná (UTFPR), Dois Vizinhos, Paraná, Brazil.

${ }^{7}$ Postgraduate Program in Agroecosystems (PPGSIS), Federal Technological University of Paraná (UTFPR), Dois Vizinhos, Paraná, Brazil.

Correspondence Author: Thayllane de Campos, Federal Technological University of Paraná (UTFPR), Department of Agronomy, Estrada para Boa Esperança Km 4, Dois Vizinhos, PR.ZIP code: 85660-000.

E-mail: thayllanedecampos@hotmail.com

Received date: 12 August 2018, Accepted date: 15 November 2018, Online date: 27 November 2018

Copyright: () 2018 David Marlon Dalposso,et al, This is an open-access article distributed under the terms of the Creative Commons Attribution License, which permits unrestricted use, distribution, and reproduction in any medium, provided the original author and source are credited.

\begin{abstract}
The demand for food on a worldwide scale means that new studies aimed at maximizing production and at integrated systems are being carried out, such that in the same area distinct products can be obtained, whether of forest, agricultural or livestock origin. The present study has the objective of evaluating the allelopathic potential of extracts from dry and green Pinus taeda needles on the germination and initial growth of Brachiaria riziziensis seeds. The experiment was conducted at the Laboratório de Sementes da Universidade Tecnológica Federal do Paraná (Seed Laboratory of the Federal Technological University of Paraná), Dois Vizinhos Campus, Brazil. Allelopathic effects of green P. taeda needles on the germination and initial growth of $B$. riziziensis were found, that is, on all the analyzed variables a greater effect was shown in accordance with increased concentration of the extract.
\end{abstract}

Key words: Allelochemical compounds; vegetable extracts; silvopastoral; pinus; brachiaria

\section{INTRODUCTION}

The fungus Rhizoctonia solani is a necrotrophic soil inhabiting a wide range of hosts, such as rice, potato, bean and melon (MICHEREFF et al., 2005). In addition, it has structures of resistance, which allow the survival of the fungus from one crop to another and make it difficult to control.

Phosphites are foliar fertilizers, which are being used in the control of various fungal diseases. The phosphite is formed by the reduction of the phosphorous acid with a base (CAIXETA, 2012). Phosphoric acid has properties that can reduce sporulation of fungi, thereby reducing the incidence and severity of diseases (PANICKER; GANGADHARAN, 1999, apud SANTOS, 2008). Faced with the complexity of the pathogen management and the search for sus tainable methods of disease control in plants, the use of phosphite based products presents great potential.

Since there is no study on the action of these products in this fungus, the objective of the work was to verify the potential of the phosphites based on copper, potassium and manganese on the fungus $R$. solani in vitro.

\section{MATERIAL AND METHODS}

The experiment was conducted at the Phytosanitary Laboratory of the Universidade Tecnológica Federal do Paraná, Dois Vizinhos campus.

The isolates of the fungus $R$. solani were obtained from the fungi collection of the laboratory. The isolates were cultured in PDA culture medium and used after 10 days of growth.

The products used in the experiment were phosphites based on potassium, copper and manganese. The concentrations used were standardized in the values of $10 \mu \mathrm{L}, 20 \mu \mathrm{L}, 40 \mu \mathrm{L}$ and $60 \mu \mathrm{L}$ and for the control treatment only culture medium was used. Subsequently, the pH of the medium was adjusted to 6.5 .

The experimental plots were composed of glass Petri ${ }^{\circledR}$ plates, which were eight centimeters in diameter. A completely randomized design with four replications was used.

The PDA culture medium was arranged in the amount of $100 \mathrm{ml}$ in five Erlenmeyer's. Afterwards, all materials were autoclaved at $121{ }^{\circ} \mathrm{C}$ for 15 minutes In laminar flow chamber, the products were added in due concentrations to the culture media. Afterwards, they were poured into the Petri ${ }^{\circledR}$ plates and, after solidification, a disc containing $5 \mathrm{~mm}$ diameter of the fungus $R$. solani was inserted.

The plates were sealed with film paper and incubated in BOD at $25^{\circ} \mathrm{C} \pm 2{ }^{\circ} \mathrm{C}$ and photoperiod of 12 hours for 10 days, where evaluations were carried out during the growth of the fungus until reaching the edge of the plate. 


\section{RESULTS AND DISCUSSION:}

The results observed in Figure 1 demonstrated an inverse effect for the factors concentrations and mycelial growth of the fungus. As the concentrations increased, there was a progressive reduction of mycelial growth of the microorganism. However, it can be noted that there were no significant differences between the three products tested, and it can be stated that all are effective in the control of $R$. solani in vitro.

The best results were obtained with the $60 \mu \mathrm{L}$ dose for all products (copper, manganese and potassium phosphite). It can be seen that at this dose, the mycelial growth was below $2 \mathrm{~mm}$, whereas in the absence of the phosphite, that is, dose 0 , the growth reached $8 \mathrm{~mm}$ in the same period of time and the same culture conditions.

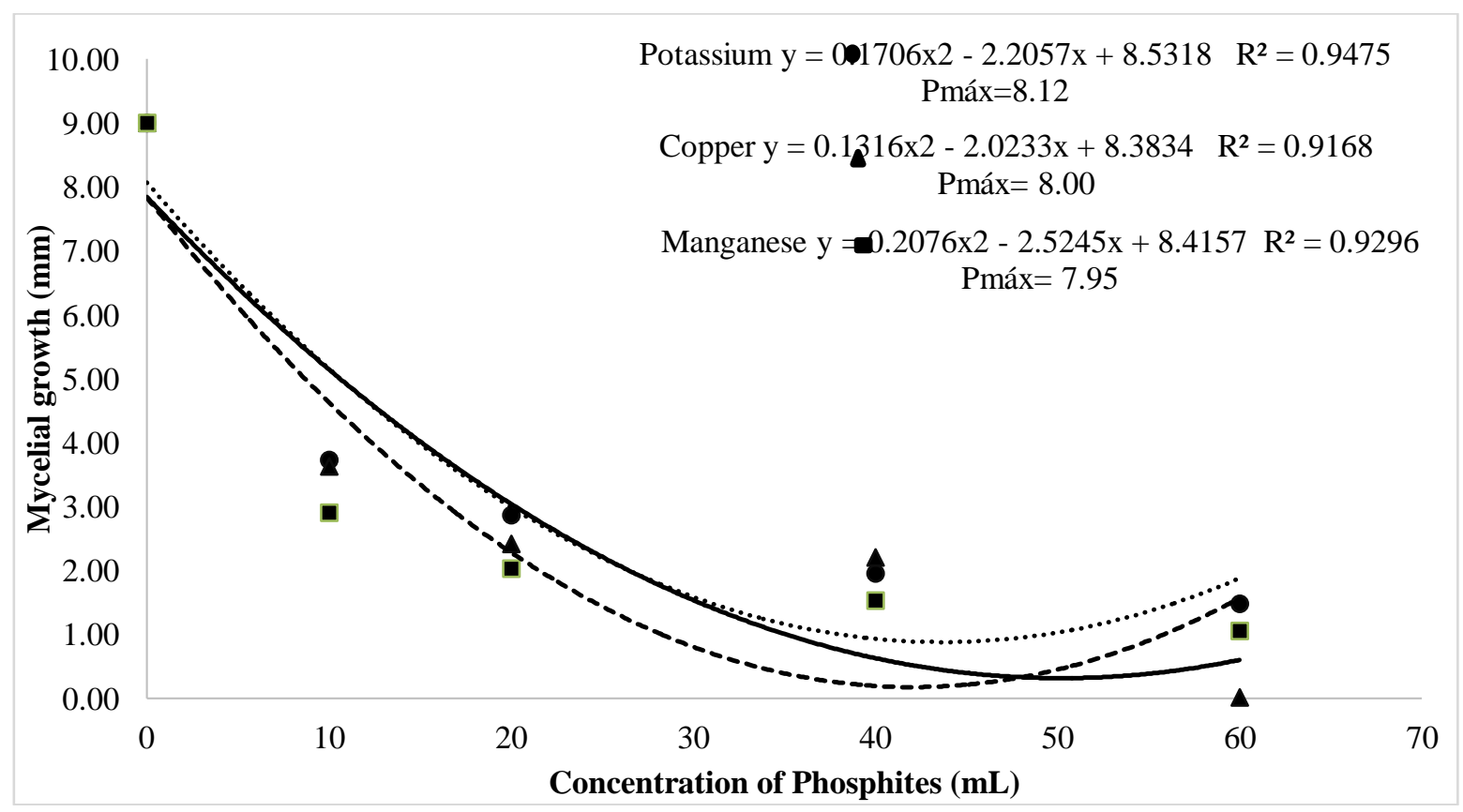

Figure 1. Mycelial growth as a function of the dose of Ultra $\mathrm{K} 10^{\circledR}$, Ultra $\mathrm{Mn} 10^{\circledR}$ and CUBO $700^{\circledast}$ products.

Potassium phosphite has been extensively tested for pathogen control. As reported by Schurt (2013), where the potassium phosphite efficiency in vitro was tested on R. solani and positive results were obtained on the control of mycelial growth of the pathogen.

Mogollon (2012) also verified the action of potassium phosphite on Mycosphaerella fijiensis Morelet and observed complete inhibition of fungus growth and reduction in spore germination.

The products based on manganese and copper phosphite do not present reports of their action on the pathogen $R$. solani in the literature. What can be raised is that the action of phosphite is systemic, reducing intensely the mycelial growth, the release of spores, besides having a toxic action for some species of fungi (FEN, 1989), caused fungitoxic and fungicidal action for $R$. solani, at the concentrations tested.

According to the study done by Mc Donald (2001), the phosphite was tested in Phytophotora and it can be verified that the action of the product is first within the pathogen and later on the host plant. The metabolism of Phytophotora was disturbed by the action of phosphorus, causing accumulation of polyphosphate and pyrophosphate, being toxic to the pathogen, inhibiting key pyrophosphoryls reactions to fungus anabolism (NIERE, 1994).

In addition, it has been observed that phosphite can act by inhibiting several fungal enzymes, not only by acting at a specific site, which demonstrates a broad spectrum of action of the product (STEHMANN, 2000).

\section{CONCLUSION}

It can be verified that the products based on phosphite were effective in controlling the pathogen Rhizoctonia solani, in both concentrations used, and with 60 $\mu \mathrm{L}$ the fungus showed low development. Demonstrating that in vitro the products can be used for inhibition of mycelial growth, however future studies should be performed aiming at the performance of the products under the pathogen under in vivo conditions.

\section{ACKNOWLEDGMENT}

The authors are grateful to the Universidade Tecnológica Federal do Paraná (UTFPR) Dois Vizinhos - PR and Pato Branco - PR campuses, for their support and resources.

\section{REFERENCES}

Caixeta, A.O. Vieria, B.S. Canedo, E.J. 2012. Efeito do fosfito de potássio sobre fungos fitopatogênicos do feijoeiro. Revista do Centro Universitário de Pato de Minas. v.3. pg. 35-43. Patos de Minas

Fenn, M.E.; Coffey, M.D. 1989. Quantification of Phosphonate and Ethyl Phosphonate in Tobacco and Tomato Tissues and its Significance for the Mode of Action of Two Phosphonate Fungicides. Phytopathology, p. 79-82

Michereff, S.J. et al. 2005. Importância dos patógenos e das doenças radiculares em solos tropicais. In: Michereff, S.J. et al. Ecologia e manejo de patógenos radiculares em solos tropicais. Recife: UFRPE, Cap.1, p.1-18.

Mc Donald, A.E. Grant, B.R. Plaxton, W.C. 2001. Phosphite (phosphorous acid): its relevance in the environment and agriculture and influence on plant phosphate starvation response. Journal of Plant Nutrition, v.24, p.1505-1519

Mogollon Ortiz, Á. M. \& Castano Zapata, J. 2012. Evaluación in vitro de Inductores de Resistencia sobre Mycosphaerella fijiensis Morelet. Revista Faculdade Nacional de Agronomía. pg. 6327-6336

Niere, J.O.; Griffith, J.M. 1990.; Grant, B.R. 31P-NMR Studies on the Effect of Phosphite on Phytophthora palmivora. J. Gen. Microbiol, p.136-156. 156

Santos, H.A.A. 2008. Efeito de fosfito no controle de doenças foliares do trigo in vitro e in situ. Mestrado em Agronomia. Curso de pós- graduação em Concentração em agricultura. Universidade Estadual de Ponta Grossa. 148 p. 
Citation: David Marlon Dalposso, et al. 2018. Allelopathy of Pinus taeda needles on the Germination and Initial Growth of Brachiaria riziziensis.Australian Journal of Basic and Applied Sciences. 12(11): 61-63. DOI: 10.22587/ajbas.2018.12.11.12

Schurt, D.A. et.al. 2013. Eficiência de diferentes moléculas na redução dos sintomas da queima das bainhas em arroz e no crescimento de Rhizoctonia solani in vitro. Revista Ceres. v.60. n.2. pg. 221-225. Viçosa

Stehmann, C. 2000. ; Grant, B.R. Inhibition of Enzymes of the Glycolytic Pathwayand Hexose Monophosphate Bypass by Phosphonate. Pest. Biochem. Physiol, 